\title{
Effects of light intensity and photoperiod on runner plant propagation of hydroponic strawberry transplants under LED lighting
}

\author{
Jianfeng Zheng, Dongxian He, Fang Ji* \\ (Key Laboratory of Agricultural Engineering in Structure and Environment of Ministry of Agriculture and Rural Affairs, \\ College of Water Resources and Civil Engineering, China Agricultural University, Beijing 100083, China)
}

\begin{abstract}
Vegetative propagation of strawberry (Fragaria $\times$ ananassa Duch.) in the plant factory with artificial lighting is considered as an effective approach to produce high-quality transplants. In this study, mother plants of 'Benihoppe' strawberry were grown hydroponically for $50 \mathrm{~d}$ under eight LED lighting treatments by combining four levels of light intensity $\left(200,250,300\right.$ and $\left.350 \mu \mathrm{mol} /\left(\mathrm{m}^{2} \cdot \mathrm{s}\right)\right)$ and two photoperiods $(12 \mathrm{~h} / \mathrm{d}$ and $16 \mathrm{~h} / \mathrm{d})$. Runner development, growth of runner plants, photon yield and energy yield in runners and runner plants were investigated to evaluate the strawberry propagation efficiency. Results indicated that length of runners decreased linearly with increasing daily light integral (DLI) under each photoperiod and was significantly shorter under photoperiod of $16 \mathrm{~h} / \mathrm{d}$. Runner elongation was inhibited by high DLI. Number of runners and runner plants formed by mother plants increased by $38.9 \%$ and $33.7 \%$, when DLI increased from 8.6 to $11.5 \mathrm{~mol} /\left(\mathrm{m}^{2} \cdot \mathrm{d}\right)$, respectively; however, no further increase was observed when DLI was higher than $11.5 \mathrm{~mol} /\left(\mathrm{m}^{2} \cdot \mathrm{d}\right)$. Similar trends were found in crown diameter and biomass of primary and secondary runner plants. Negative impact of high DLI $\left(20.2 \mathrm{~mol} /\left(\mathrm{m}^{2} \cdot \mathrm{d}\right)\right)$ on photosynthetic capacity of runner plants was observed as a decrease in leaf net photosynthetic rate, potential maximum photochemical efficiency of PSII, and chlorophyll content. Furthermore, photon yield and energy yield in runners and runner plants decreased significantly with increasing DLI. Therefore, DLI in a range of $11.5-17.3 \mathrm{~mol} /\left(\mathrm{m}^{2} \cdot \mathrm{d}\right)$ is beneficial to improve strawberry propagation efficiency and quality of runner plants, and $11.5 \mathrm{~mol} /\left(\mathrm{m}^{2} \cdot \mathrm{d}\right)$ is optimal for the strawberry propagation of runner plants in the LED plant factory because of the higher photon and energy yields.
\end{abstract}

Keywords: hydroponic strawberry, vegetative propagation, daily light integral, photon yield DOI: $10.25165 /$ j.ijabe.20191206.5265

Citation: Zheng J F, He D X, Ji F. Effects of light intensity and photoperiod on runner plant propagation of hydroponic strawberry transplants under LED lighting. Int J Agric \& Biol Eng, 2019; 12(6): 26-31.

\section{Introduction}

Commercial strawberry (Fragaria $\times$ ananassa Duch.) transplants are usually propagated vegetatively by runners. The runner plant propagation rate and plant quality are susceptibly influenced by environmental conditions such as temperature, photoperiod, diseases, and so on in the field and low-tech greenhouses $^{[1-3]}$. An effective approach for vegetative propagation of high quality transplants is to produce in a plant factory with artificial lighting (PFAL) under precisely controlled environment ${ }^{[4,5]}$. Productivity of strawberry plug transplants in the PFAL was 110-140 times greater than that by using conventional propagation methods ${ }^{[6]}$. Generally, light-emitting diode (LED) light is used as the sole-source lighting for plant growth in the PFAL. Light intensity and photoperiod determine the daily light integral (DLI), which is closely related to electricity input for LED lighting. The electrical energy consumption of lighting is approximate $70 \%$ to $80 \%$ of total electricity consumption for year-round production in PFALs ${ }^{[7]}$. It is

Received date: 2019-07-05 Accepted date: 2019-10-30

Biographies: Jianfeng Zheng, PhD Candidate, research interests: strawberry propagation and plant factory technology, Email: zjf@cau.edu.cn; Dongxian He, $\mathrm{PhD}$, Professor, research interests: plant environmental physiology and plant factory technology, Email: hedx@cau.edu.cn.

*Corresponding author: Fang $\mathbf{J i}, \mathrm{PhD}$, Lecturer, research interests: plant environmental physiology. Key Laboratory of Agricultural Engineering in Structure and Environment of Ministry of Agriculture and Rural Affairs, College of Water Resources and Civil Engineering, China Agricultural University, Beijing 100083, China. Tel: +86-10-62737550, Email: jifang@cau.edu.cn. necessary to determine the optimal combination of light intensity and photoperiod for efficient production of strawberry transplants under LED lighting in PFAL.

High light intensity generally promotes runner formation and runner plant growth. In air-conditioned glasshouses, more runners were produced by mother plants when suitable light intensity during the day or the light intensity of the supplemental light for extending the photoperiod were increased ${ }^{[8]}$. In a closed transplant production system using fluorescent light, strawberry mother plants grown under $280 \mu \mathrm{mol} /\left(\mathrm{m}^{2} \cdot \mathrm{s}\right)$ produced more runners than those grown under $210 \mu \mathrm{mol} /\left(\mathrm{m}^{2} \cdot \mathrm{s}\right)$ and $140 \mu \mathrm{mol} /\left(\mathrm{m}^{2} \cdot \mathrm{s}\right)$, and runner plant growth was improved by increasing light intensity during strawberry transplant propagation ${ }^{[9]}$. Wu et al. ${ }^{[10]}$ compared the effect of different light quality and light intensity on runner plant propagation of 'Toyonoka' strawberry plants under fluorescent light and found that cool white quality in color temperature of $6500 \mathrm{~K}$ and $5000 \mathrm{~K}$ with high light intensity $\left(110-122 \mu \mathrm{mol} /\left(\mathrm{m}^{2} \cdot \mathrm{s}\right)\right)$ promoted runner formation and runner plant growth compared with warmer color quality in color temperature of $4000 \mathrm{~K}$ and $3000 \mathrm{~K}$ with lower light intensity $\left(50-55 \mu \mathrm{mol} /\left(\mathrm{m}^{2} \cdot \mathrm{s}\right)\right)$. Furthermore, increasing light intensity for mother plants rather than runner plants was more effective in enhancing the growth of runner plants. Thus, the efficiency of strawberry propagation in a plant factory may be improved by decreasing light intensity for runner plants $^{[11]}$.

Photoperiod affects formation and elongation of runners. Everbearing strawberry 'Natsuakari' plants produced more runners under longer photoperiod than $10 \mathrm{~h} / \mathrm{d}$ and $12 \mathrm{~h} / \mathrm{d}^{[12]}$. The number of runners and runner plants per mother plant increased 
significantly when photoperiod was extended to $15 \mathrm{~h} / \mathrm{d}$ by using fluorescent light with light intensity of approximately $1 \mu \mathrm{mol} /\left(\mathrm{m}^{2} \cdot \mathrm{s}\right)^{[13]}$. Strawberry runners and petioles differentiated and elongated under short-day had shorter length compared to those growing under long-day, resulting from shorter cell length and fewer number of cells ${ }^{[14,15]}$.

Although the effect of light intensity on runner plant propagation in the plant factory by using fluorescent light has been investigated, the influence of photoperiod or the combined effects of light intensity and photoperiod still needs to be studied further, especially when using LED lights, which are expected to reduce the electricity $\operatorname{costs}^{[16,17]}$. Therefore, purpose of this study was to investigate the effects of light intensity and photoperiod on runner plant propagation of hydroponic strawberry under LED lighting.

\section{Materials and methods}

\subsection{Plant materials and growth conditions}

Strawberry 'Benihoppe' transplants, which are widely produced commercially in China, were chosen as plant material in this experiment. The micropropagated strawberry plants were acclimated in hydroponics. A total of 64 acclimated transplants having $3.3 \pm 0.5$ leaves and $10.7 \pm 0.7 \mathrm{~mm}$ crown diameters were selected as mother plants for runner plant propagation. The mother plants were planted in two vertical hydroponic transplant propagation systems (Figure 1). Each system consists of four cultivation beds and one solution tank. Each hydroponic cultivation bed $(1200 \mathrm{~mm} \times 900 \mathrm{~mm} \times 70 \mathrm{~mm})$ had 117 planting holes ( $25 \mathrm{~mm}$ in diameter). In the central region of the bed, eight mother plants were planted, and the remaining planting holes were plugged with sponges $(25 \mathrm{~mm} \times 25 \mathrm{~mm} \times 25 \mathrm{~mm})$. During the experiment, runner plants at one-leaf stage were placed in a waterlogged sponge. Roots of runner plants gradually penetrated through the sponge and touched the nutrient solution in about three days. The runner plants were harvested at 50 days after planting the mother plants when the cultivation beds were fully covered with runner plants. Nutrient solution was prepared according to Yamasaki strawberry formula (N 77, P 15.5, K 117, Ca 40, Mg 12, $\mathrm{S} \mathrm{16,} \mathrm{Fe} \mathrm{2,} \mathrm{Mn} \mathrm{0.2,} \mathrm{B} \mathrm{0.2,} \mathrm{Zn} \mathrm{0.02,} \mathrm{Cu} \mathrm{0.01,} \mathrm{Mo} 0.005 \mathrm{mg} / \mathrm{L}$ ) and continuously recirculated $(5.5 \mathrm{~L} / \mathrm{min})$ among four cultivation beds and the solution tank in each hydroponic system. Electrical conductivity and $\mathrm{pH}$ of the nutrient solution were maintained at $0.6-0.8 \mathrm{mS} / \mathrm{cm}$ and $6.0-6.5$, respectively. The nutrient solution was renewed every 7 days during the experiment. Air temperature in the growth chamber was maintained at $(25 \pm 1)^{\circ} \mathrm{C} /(20 \pm 1)^{\circ} \mathrm{C}$ during light/dark period. Average daily relative humidity was $75 \% \pm 10 \% . \quad \mathrm{CO}_{2}$ concentration was enhanced to $(800 \pm 50) \mu \mathrm{mol} / \mathrm{mol}$ during light period and without control during dark period.

\subsection{Lighting treatments}

Tube-type LED lights consisting of white chips and red chips (WR-LED5/1-16W, Beijing Lighting Valley Technology Company Ltd., China) were installed at $30 \mathrm{~cm}$ above the cultivation bed. The spectral distribution of LED lighting was measured under $15 \mathrm{~cm}$ from the lights in wavelength ranging from $300 \mathrm{~nm}$ to $800 \mathrm{~nm}$ using a fiber spectrometer (AvaField-2, Avantes Inc., The Netherland). The photon flux of lighting was composed of $0.1 \%$ ultraviolet (300-399 nm), 24.7\% blue (400-499 nm), 43.6\% green $(500-599 \mathrm{~nm}), 29.7 \%$ red $(600-699 \mathrm{~nm})$ and $1.9 \%$ far red $(700-$ $800 \mathrm{~nm})$ light, respectively. Eight lighting treatments were created by combinations of four levels of light intensity $(200,250$, 300 and $\left.350 \mu \mathrm{mol} /\left(\mathrm{m}^{2} \cdot \mathrm{s}\right)\right)$ and two photoperiods $(12 \mathrm{~h} / \mathrm{d}$ and $16 \mathrm{~h} / \mathrm{d})$
(Table 1). Each cultivation bed holding eight mother plants was exposed to one lighting treatment. Light intensities were measured at nine evenly distributed points at $15 \mathrm{~cm}$ below the LED lights using a portable quantum meter (LI-250A, LI-COR Biosciences Inc., USA). Four light intensity levels, 203 \pm 6 , $247 \pm 10,298 \pm 12$, and $347 \pm 13 \mu \mathrm{mol} /\left(\mathrm{m}^{2} \cdot \mathrm{s}\right)$ were achieved by changing the number and location of LED lights.

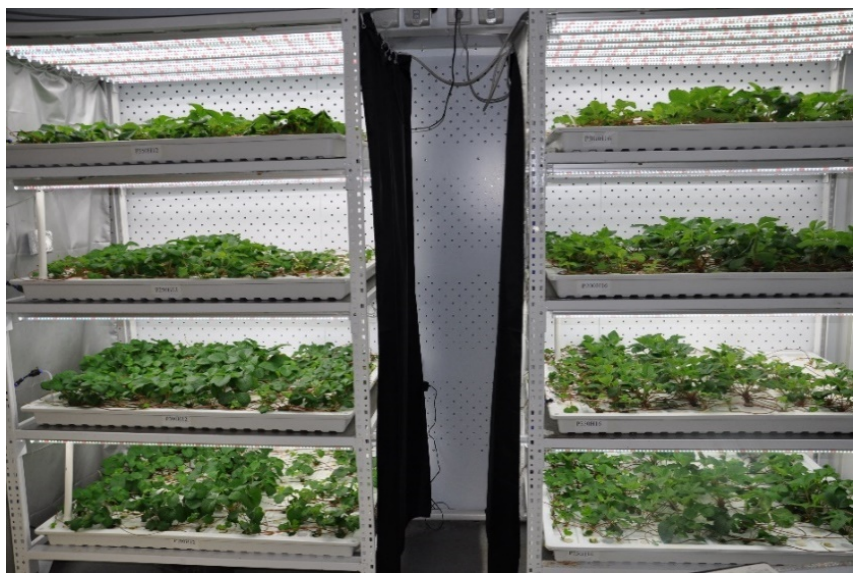

Figure 1 Hydroponic strawberry transplant propagation system using LED lighting

Table 1 Lighting treatments created by combinations of four levels of light intensity $(\mathrm{L})$ and two levels of photoperiod $(\mathrm{H})$

\begin{tabular}{cccccc}
\hline $\begin{array}{c}\text { Treatment } \\
\text { symbol }\end{array}$ & $\begin{array}{c}\text { Light } \\
\text { intensity } \\
/ \mu \mathrm{mol} \cdot \mathrm{m}^{-2} \cdot \mathrm{s}^{-1}\end{array}$ & $\begin{array}{c}\text { Photoperiod } \\
/ \mathrm{h} \cdot \mathrm{d}^{-1}\end{array}$ & $\begin{array}{c}\mathrm{DLI} \\
/ \mathrm{mol} \cdot \mathrm{m}^{-2} \cdot \mathrm{d}^{-1}\end{array}$ & $\begin{array}{c}\text { Number of } \\
\text { LED lights } \\
\text { in each bed }\end{array}$ & $\begin{array}{c}\text { Total power } \\
\text { in each bed } \\
/ \mathrm{W}\end{array}$ \\
\hline L200-H12 & 200 & & 8.6 & 7 & 106.4 \\
L250-H12 & 250 & 12 & 10.8 & 9 & 136.8 \\
L300-H12 & 300 & 12 & 13.0 & 11 & 167.2 \\
L350-H12 & 350 & & 15.1 & 13 & 197.6 \\
\hline L200-H16 & 200 & & 11.5 & 7 & 106.4 \\
L250-H16 & 250 & \multirow{2}{*}{16} & 14.4 & 9 & 136.8 \\
L300-H16 & 300 & & 17.3 & 11 & 167.2 \\
L350-H16 & 350 & & 20.2 & 13 & 197.6 \\
\hline
\end{tabular}

Note: DLI represents daily light integral, DLI $\left(\mathrm{mol} /\left(\mathrm{m}^{2} \cdot \mathrm{d}\right)\right)=$ light intensity $\left(\mu \mathrm{mol} /\left(\mathrm{m}^{2} \cdot \mathrm{s}\right)\right) \times$ photoperiod $(\mathrm{h} / \mathrm{d}) \times 3600(\mathrm{~s} / \mathrm{h}) \times 10^{-6}$. L200-H12 represents light intensity of $200 \mu \mathrm{mol} /\left(\mathrm{m}^{2} \cdot \mathrm{s}\right)$ and photoperiod of $12 \mathrm{~h} / \mathrm{d}$.

\subsection{Measurements and calculations}

\subsubsection{Growth characteristics of runners and runner plants}

The number of runners formed by mother plants was counted every two days. The length of runners sprouting from the mother plant was measured every day using a ruler. At the end of the experiment, number of primary runner plants formed by mother plants, number of secondary runner plants originating from the primary runner plants, and number of tertiary runner plants formed from the secondary runner plants were counted, and total number of runner plants was calculated. Growth characteristics (crown diameter, leaf number, and dry weight) of the primary runner plants and secondary runner plants were determined. The crown diameter of runner plants was measured using a digital Vernier caliper. Leaf count was based on unfolded trifoliate leaves of runner plants. Runner plants were dried in an oven at a temperature of $105^{\circ} \mathrm{C}$ for $3 \mathrm{~h}$ and then at $70^{\circ} \mathrm{C}$ until constant weight. Dry weight of runner plants was measured using an electronic analytical balance (AX622ZH, Ohaus Instruments (Shanghai) Co., Ltd, China).

2.3.2 Net photosynthetic rate, chlorophyll fluorescence, and chlorophyll content

The third unfolded leaf from the central leaf of the mother 
plants and the primary runner plants were selected to measure net photosynthetic rate, chlorophyll fluorescence, and chlorophyll content at day 50. Net photosynthetic rate was measured using a portable photosynthesis system (LI-6400XT, LI-COR Biosciences Inc., USA) with a leaf chamber with red and blue LED light sources. In the leaf chamber, light intensity, air temperature, and $\mathrm{CO}_{2}$ concentration were set at $400 \mu \mathrm{mol} /\left(\mathrm{m}^{2} \cdot \mathrm{s}\right), 25^{\circ} \mathrm{C}$, and $800 \mu \mathrm{mol} / \mathrm{mol}$, respectively. Chlorophyll fluorescence was measured using a chlorophyll fluorescence monitoring system (M-PEA, Hansatech Instruments Ltd., UK). Leaf chlorophyll was extracted in $80 \%$ acetone and absorbance of extracted solution were measured at $663 \mathrm{~nm}$ and $645 \mathrm{~nm}$ using a spectrophotometer (UV-3150, Shimadzu Corporation, Japan). Chlorophyll content was calculated according to Arnon's Equations ${ }^{[18]}$.

2.3.3 Photon yield and energy yield in runners and runner plants

Photon yield and energy yield were calculated to assess the efficiency of electric light sources for cultivating crops in a plant factory ${ }^{[19]}$. Briefly, photon yield in runners is calculated as the number of runners produced per mole photons during the entire propagation period. And energy yield in runners is calculated as the number of runners produced per kilowatt-hour electricity. Similarly, photon yield and energy yield in runner plants are calculated based on the number of runner plants.

\subsection{Statistical analysis}

The experiments were repeated independently for three times. The data were shown as mean \pm standard deviation $(n=6)$. Statistical analysis was performed using SPSS 21.0 (IBM, Inc., Chicago, IL, USA). All data were analyzed for significance by analysis of variance (ANOVA) followed by the Duncan's multiple range test for mean separation at $p \leq 0.05$.

\section{Results and discussion}

\subsection{Effects of light intensity and photoperiod on formation and elongation of runners}

Runner length increased with time following the Gompertz growth model (Figures 2a and 2b). Around $15 \mathrm{~d}$ after sprouting, the runner length gradually stabilized, which means elongation gradually ceased. The runner tip started to develop into a primary runner plant. The final length of the primary runner, affected by light intensity and photoperiod, was longest $(36.0 \mathrm{~cm})$ at $200 \mu \mathrm{mol} /\left(\mathrm{m}^{2} \cdot \mathrm{s}\right)$ with photoperiod of $12 \mathrm{~h} / \mathrm{d}$ and shortest $(23.3 \mathrm{~cm})$ at $350 \mu \mathrm{mol} /\left(\mathrm{m}^{2} \cdot \mathrm{s}\right)$ with photoperiod of $16 \mathrm{~h} / \mathrm{d}$. Length of runners decreased with increasing light intensity regardless of photoperiod. A similar result was reported by Kim et al. ${ }^{[9]}$ that length of primary runner and secondary runner decreased as light intensity increased from $140 \mu \mathrm{mol} /\left(\mathrm{m}^{2} \cdot \mathrm{s}\right)$ to $280 \mu \mathrm{mol} /\left(\mathrm{m}^{2} \cdot \mathrm{s}\right)$. It is worth noting that the primary runner under $16 \mathrm{~h} / \mathrm{d}$ had a shorter length than that under $12 \mathrm{~h} / \mathrm{d}$ when light intensity was same. This result was different from previous studies ${ }^{[13,15]}$ that runners were longer under long-day than short-day owing to the increase in number and length of epidermal cells. The discrepancy may be due to the differences in light intensity during the extended photoperiod. Hasan et al. ${ }^{[13]}$ and Nishizawa ${ }^{[15]}$ created long photoperiod by extending daylength using incandescent or fluorescent light with light intensity of no more than $5 \mu \mathrm{mol} /\left(\mathrm{m}^{2} \cdot \mathrm{s}\right)$, which is extremely lower than the light compensation point of strawberry leaves. Mother plants have shorter runner length and increased clonal branching under favorable environments ${ }^{[20]}$. Extending photoperiod with light intensity below the compensation point might give a signal to the mother plant that it is under light deprivation. The runners would stretch out to let runner plants avoid unfavorable conditions.

Length of primary runners decreased linearly with increasing DLI, and the decreasing slope was smaller under $16 \mathrm{~h} / \mathrm{d}$ than $12 \mathrm{~h} / \mathrm{d}$ (Figure 2c). Similar trend was found in the average internode elongation of Tecoma stans as DLI increased from $0.75 \mathrm{~mol} /\left(\mathrm{m}^{2} \cdot \mathrm{d}\right)$ to $15.6 \mathrm{~mol} /\left(\mathrm{m}^{2} \cdot \mathrm{d}\right)^{[21]}$. Height of Impatiens and Salvia decreased by $27 \%$ and $37 \%$, as DLI increased from 4.1 to $14.2 \mathrm{~mol} /\left(\mathrm{m}^{2} \cdot \mathrm{d}\right)^{[22]}$, respectively. Increasing DLI reduced the internode elongation and height of flowers. Our study indicated that runner elongation was inhibited by high DLI. Shorter runners mean a smaller space requirement for mother plants during propagation, thus improving runner plants yield per unit area and using the space more efficiently in a plant factory.

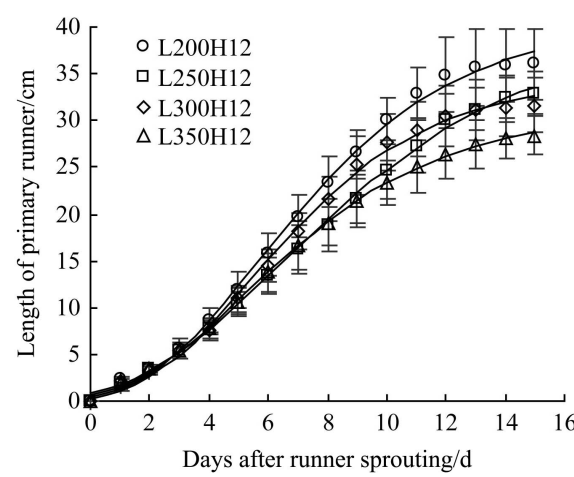

a.

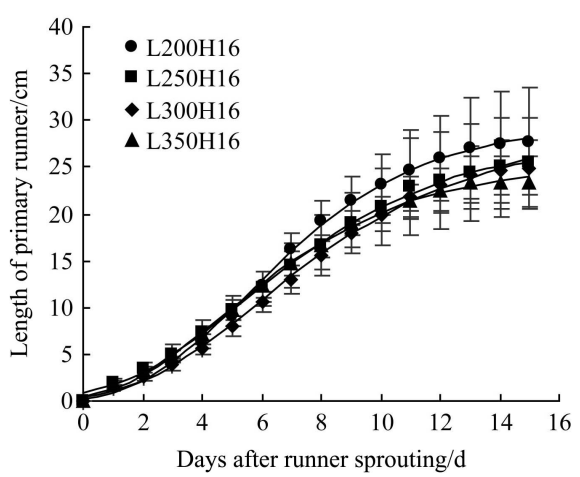

b.

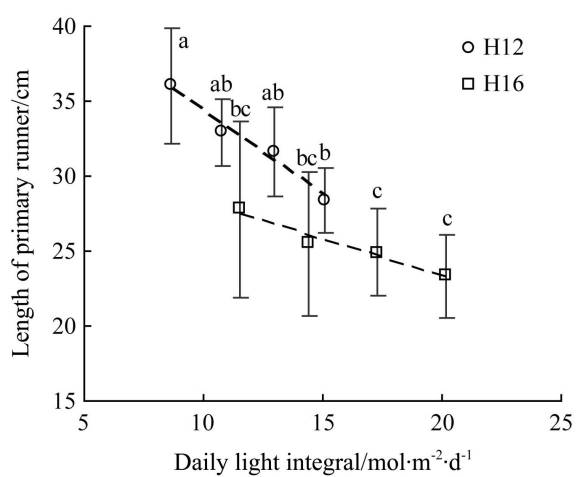

c.

Note: Letters a-c indicate significant differences according to Duncan's multiple range test at $p \leq 0.05$ ( $n=6$ ). Vertical bars represent standard deviations.

Figure 2 Time courses of length of primary runners as affected by light intensity and photoperiod (a and b) and relationship between the length of primary runners and daily light integral (c)

Number of runners emerged from mother plants increased linearly with time in the first 30-day propagation period and then gradually reached a plateau (Figures $3 a$ and $3 b$ ). The final number of runners formed by mother plants at $50 \mathrm{~d}$ after planting increased by $27.3 \%$ as light intensity increased from $200 \mu \mathrm{mol} /\left(\mathrm{m}^{2} \cdot \mathrm{s}\right)$ to $300 \mu \mathrm{mol} /\left(\mathrm{m}^{2} \cdot \mathrm{s}\right)$; however, the number was not improved further when light intensity increased to $350 \mu \mathrm{mol} /\left(\mathrm{m}^{2} \cdot \mathrm{s}\right)$ under photoperiod of $12 \mathrm{~h} / \mathrm{d}$ (Figure $3 \mathrm{c}$ ). Moreover, number of runners did not increase when light intensity increased from $200 \mu \mathrm{mol} /\left(\mathrm{m}^{2} \cdot \mathrm{s}\right)$ to $350 \mu \mathrm{mol} /\left(\mathrm{m}^{2} \cdot \mathrm{s}\right)$ under photoperiod of $16 \mathrm{~h} / \mathrm{d}$. Number of runners can be improved by increasing the photoperiod at light intensity of $200-300 \mu \mathrm{mol} /\left(\mathrm{m}^{2} \cdot \mathrm{s}\right)$. Nevertheless, there were no significant difference in number of runners between photoperiods of $12 \mathrm{~h} / \mathrm{d}$ and $16 \mathrm{~h} / \mathrm{d}$ when light intensity was at $350 \mu \mathrm{mol} /\left(\mathrm{m}^{2} \cdot \mathrm{s}\right)$. 
Wu et al. ${ }^{[10]}$ reported that high light intensity $\left(110-122 \mu \mathrm{mol} /\left(\mathrm{m}^{2} \cdot \mathrm{s}\right)\right)$ promoted runner formation of 'Toyonoka' strawberry compared to low light intensity $\left(50-55 \mu \mathrm{mol} /\left(\mathrm{m}^{2} \cdot \mathrm{s}\right)\right)$. Kim et al ${ }^{[9]}$ reported that strawberry mother plants grown under $280 \mu \mathrm{mol} /\left(\mathrm{m}^{2} \cdot \mathrm{s}\right)$ produced more runners than those grown under $210 \mu \mathrm{mol} /\left(\mathrm{m}^{2} \cdot \mathrm{s}\right)$ and $140 \mu \mathrm{mol} /\left(\mathrm{m}^{2} \cdot \mathrm{s}\right)$. In our hydroponic strawberry transplant propagation system, number of runners formed by mother plants was affected by both light intensity and photoperiod, which was related to DLI. Number of runners increased by $38.9 \%$ when DLI increased from 8.6 to $11.5 \mathrm{~mol} /\left(\mathrm{m}^{2} \cdot \mathrm{d}\right)$, but did not change in the range from $11.5 \mathrm{~mol} /\left(\mathrm{m}^{2} \cdot \mathrm{d}\right)$ to $20.2 \mathrm{~mol} /\left(\mathrm{m}^{2} \cdot \mathrm{d}\right)$.

\subsection{Effects of light intensity and photoperiod on propagation} of runner plants

The number of primary runner plants increased by $52.6 \%$ when light intensity increased from $200 \mu \mathrm{mol} /\left(\mathrm{m}^{2} \cdot \mathrm{s}\right)$ to $300 \mu \mathrm{mol} /\left(\mathrm{m}^{2} \cdot \mathrm{s}\right)$ under photoperiod of $12 \mathrm{~h} / \mathrm{d}$ (Figure $4 \mathrm{a}$ ). However, there was no significant difference in number of primary runner plants among four levels of light intensity under photoperiod of $16 \mathrm{~h} / \mathrm{d}$. Moreover, no significant difference in number of primary runner plants was found between photoperiod of $12 \mathrm{~h} / \mathrm{d}$ and $16 \mathrm{~h} / \mathrm{d}$ regardless of light intensity. The same trends were also found in the number of secondary runner plants and total number of runner plants (Figures $4 \mathrm{~b}$ and $4 \mathrm{c}$ ). The highest number of runner plants was 14.5 per mother plant under light intensity of $300 \mu \mathrm{mol} /\left(\mathrm{m}^{2} \cdot \mathrm{s}\right)$ with photoperiod of $12 \mathrm{~h} / \mathrm{d}$ in the current study. Kim et al. ${ }^{[9]}$ reported that 'Maehyang' strawberry grown under light intensity of $280 \mu \mathrm{mol} /\left(\mathrm{m}^{2} \cdot \mathrm{s}\right)$ with photoperiod of $16 \mathrm{~h} / \mathrm{d}$ produced highest number (9.4) of runner plants per mother plant during $35 \mathrm{~d}$. If we divide the total number of runner plants by propagation days, the average propagation rate of 'Benihoppe' strawberry was 0.29 plant per day per mother plant, which was slightly higher than that $(0.27)$ for 'Maehyang' strawberry ${ }^{[9]}$.

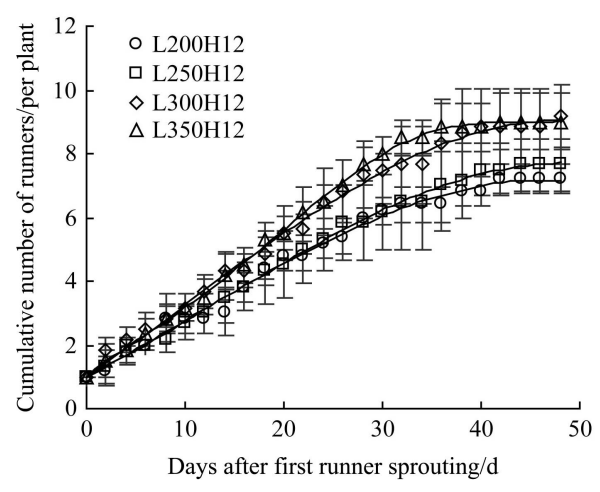

a.

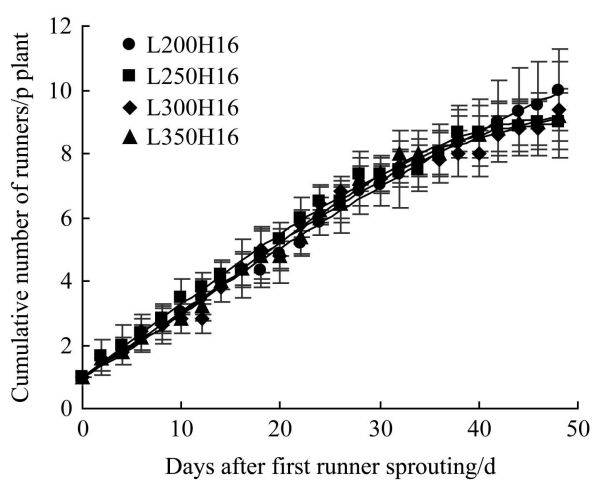

b.

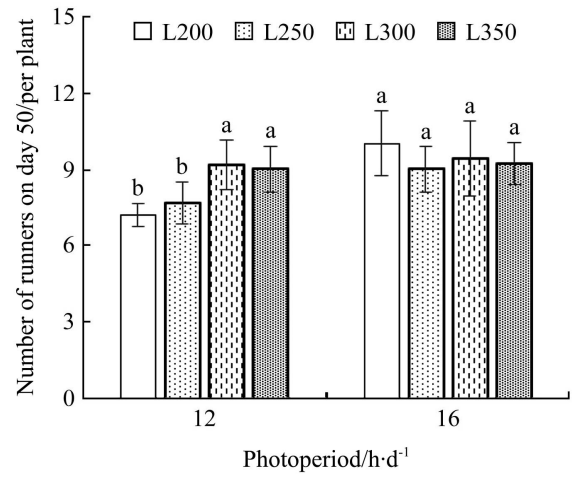

c.

Note: Letters a-b indicate significant differences according to Duncan's multiple range test at $p \leq 0.05$ ( $n=6$ ). Vertical bars represent standard deviations.

Figure 3 Time course of cumulative number of runners (a and b) and number of strawberry runners 50 days after planting as affected by light intensity and photoperiod (c)

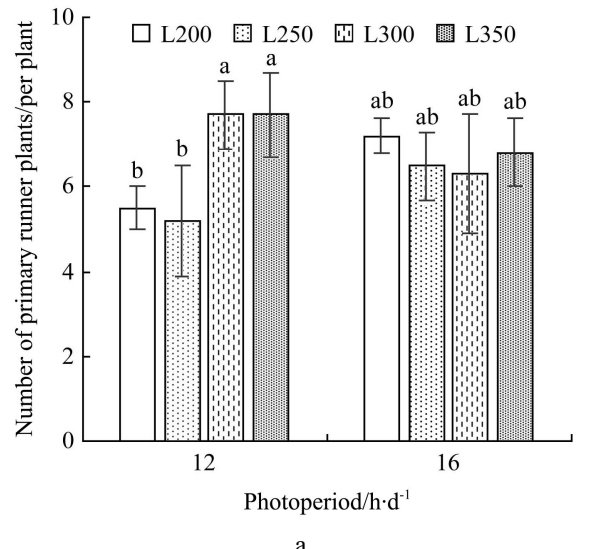

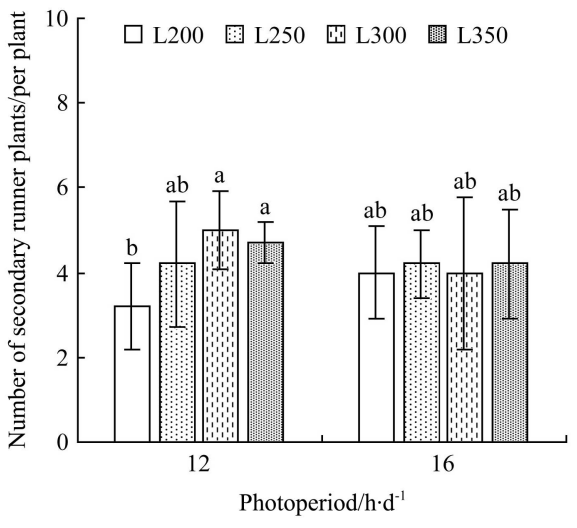

b.

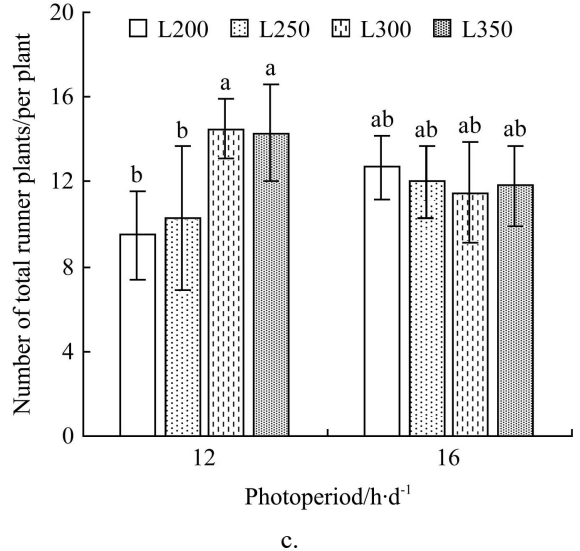

c.

Note: Letters a-b indicate significant differences according to Duncan's multiple range test at $p \leq 0.05$ ( $n=6$ ). Vertical bars represent standard deviations.

Figure 4 Number of primary runners (a), secondary runners (b), and total number of runners (c) $50 \mathrm{~d}$ after planting as affected by light intensity and photoperiod

Light intensity and photoperiod had interactive effects on crown diameter of primary runner plants and secondary runner plants (Table 2). Crown diameter under photoperiod of $16 \mathrm{~h} / \mathrm{d}$ was significantly higher than that under $12 \mathrm{~h} / \mathrm{d}$, but the difference shrunk with the increase of light intensity. Primary runner plants grown under light intensity of $300 \mu \mathrm{mol} /\left(\mathrm{m}^{2} \cdot \mathrm{s}\right)$ with photoperiod of $16 \mathrm{~h} / \mathrm{d}$ had the highest number (7.0) of leaves, while those under light intensity of $200 \mu \mathrm{mol} /\left(\mathrm{m}^{2} \cdot \mathrm{s}\right)$ with photoperiod of $12 \mathrm{~h} / \mathrm{d}$ had the lowest number (6.0) of leaves. No significant difference in number of leaves was found among secondary runner plants, since they all had about three leaves. When light intensity increased from $200 \mu \mathrm{mol} /\left(\mathrm{m}^{2} \cdot \mathrm{s}\right)$ to $300 \mu \mathrm{mol} /\left(\mathrm{m}^{2} \cdot \mathrm{s}\right)$, the dry weight of primary runner plants grown under photoperiod of $12 \mathrm{~h} / \mathrm{d}$ increased by $79.6 \%$, but no significant difference was observed under photoperiod of $16 \mathrm{~h} / \mathrm{d}$. Similar trends were found in dry weight of secondary runner plants. For the mother plants, net photosynthetic rate increased by $24.0 \%$ when light intensity increased from $200 \mu \mathrm{mol} /\left(\mathrm{m}^{2} \cdot \mathrm{s}\right)$ to $350 \mu \mathrm{mol} /\left(\mathrm{m}^{2} \cdot \mathrm{s}\right)$ under $12 \mathrm{~h} / \mathrm{d}$, but decrease was observed when light intensity increased from $300 \mu \mathrm{mol} /\left(\mathrm{m}^{2} \cdot \mathrm{s}\right)$ to $350 \mu \mathrm{mol} /\left(\mathrm{m}^{2} \cdot \mathrm{s}\right)$ under $16 \mathrm{~h} / \mathrm{d}$ (Table 3$)$. Chlorophyll content followed the same trends. However, no significant difference was found in $\mathrm{F}_{\mathrm{v}} / \mathrm{F}_{\mathrm{m}}$ among the eight 
treatments. For the primary runner plants, no significant difference was observed in net photosynthetic rate among four levels of light intensity under $12 \mathrm{~h} / \mathrm{d}$. However, decrease was observed in net photosynthetic rate, $\mathrm{F}_{\mathrm{v}} / \mathrm{F}_{\mathrm{m}}$ and chlorophyll content when light intensity increased from $300 \mu \mathrm{mol} /\left(\mathrm{m}^{2} \cdot \mathrm{s}\right)$ to $350 \mu \mathrm{mol} /\left(\mathrm{m}^{2} \cdot \mathrm{s}\right)$ under $16 \mathrm{~h} / \mathrm{d}$.

Table 2 Growth of primary runner plants and secondary runner plants as affected by light intensity and photoperiod

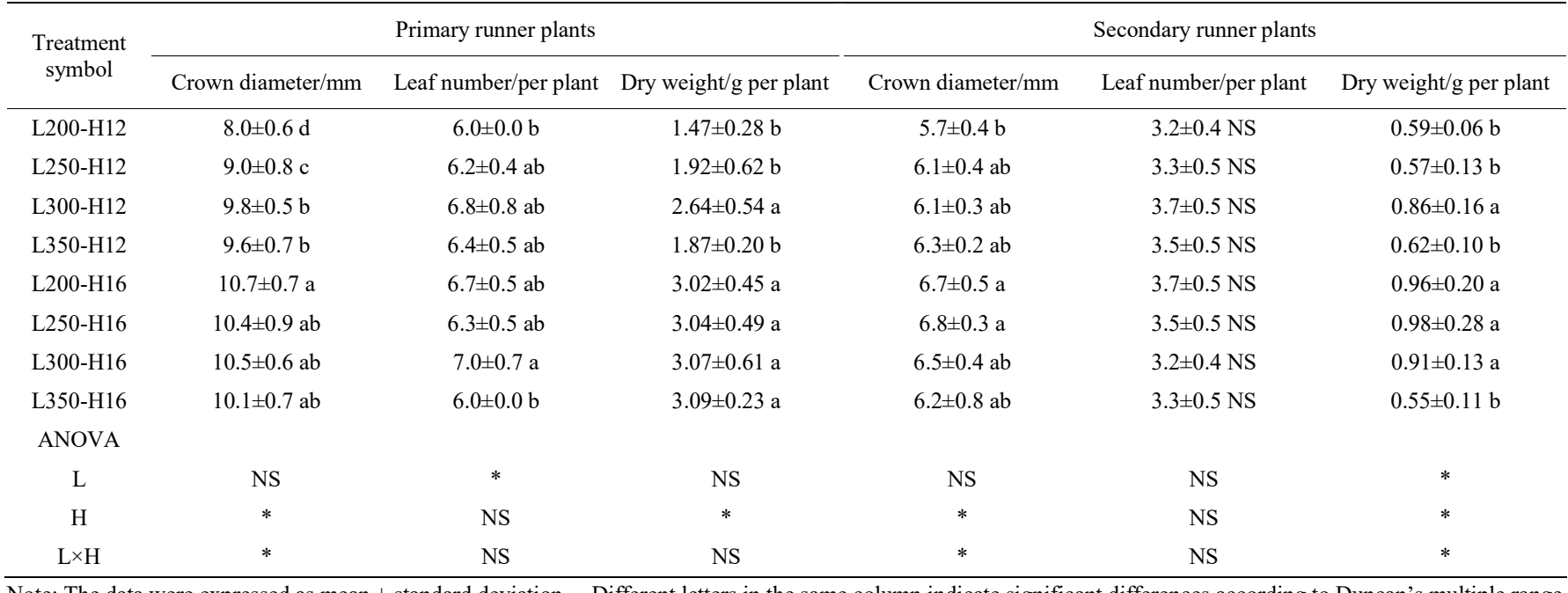

Note: The data were expressed as mean \pm standard deviation. Different letters in the same column indicate significant differences according to Duncan's multiple range test at $p \leq 0.05(n=6)$. NS and * represent nonsignificant or significant differences at $p \leq 0.05(n=6)$, respectively.

Table 3 Net photosynthetic rate $(P n)$, chlorophyll fluorescence $\left(F_{v} / F_{m}\right)$, and chlorophyll $(C h l)$ content of strawberry leaves as affected by light intensity and photoperiod

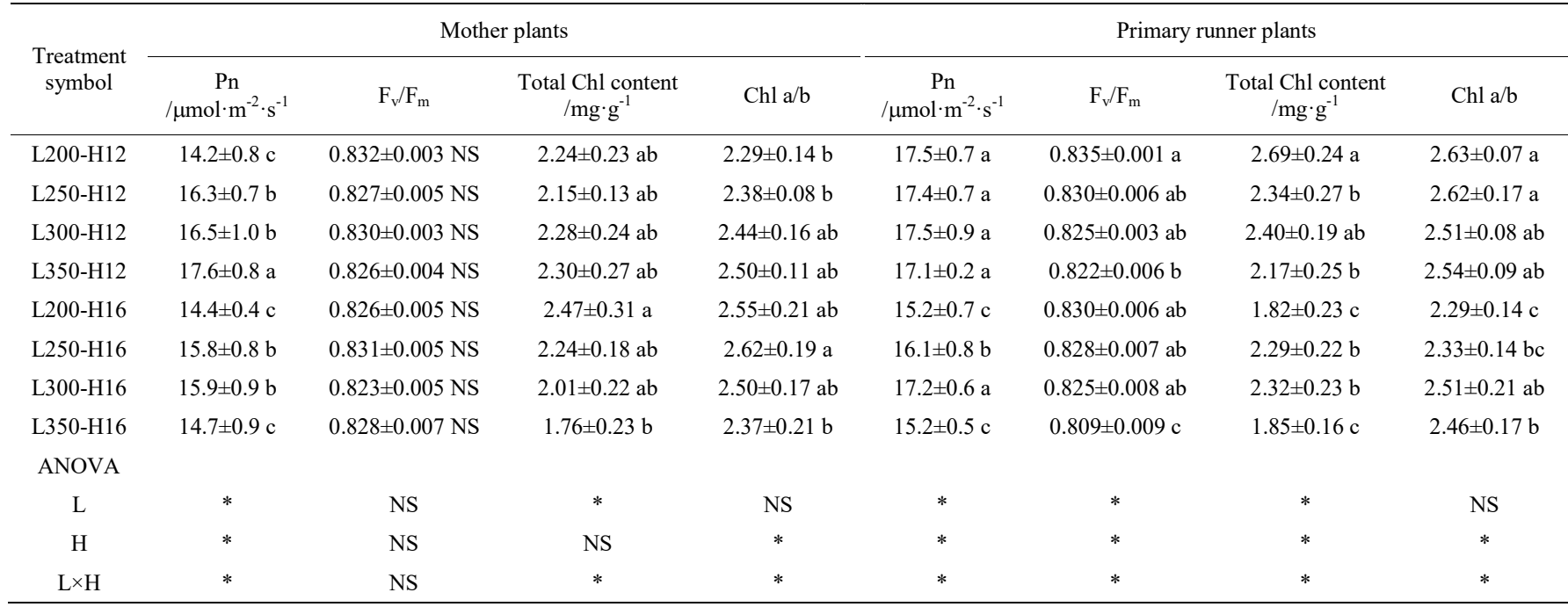

Note: The data were expressed as mean \pm standard deviation. Different letters in the same column indicate significant differences according to Duncan's multiple range test at $p \leq 0.05(n=6)$. NS and * represent nonsignificant or significant differences at $p \leq 0.05(n=6)$, respectively.

Generally, $1 \%$ increase in the amount of light results in a $1 \%$ yield increase in greenhouse grown crops, including fruit vegetables, soil grown vegetables, cut flowers, bulb flowers, flowering pot plants, and non-flowering pot plants ${ }^{[23]}$. However, biomass of primary and secondary runner plants in the current experiment did not completely follow this "rule of thumb". In fact, the biomass of runner plants under highest DLI $\left(20.2 \mathrm{~mol} /\left(\mathrm{m}^{2} \cdot \mathrm{d}\right)\right)$ had a significant decrease. Obviously, excessive light inhibited growth of runner plants, which was supported by evidences that net photosynthetic rate, $F_{v} / F_{m}$ and chlorophyll content of runner plant leaves under highest DLI were at lowest level. Similar results on bedding plants were reported that the total plant dry mass increased at a decreasing rate as DLI increased from $5 \mathrm{~mol} /\left(\mathrm{m}^{2} \cdot \mathrm{d}\right)$ to $43 \mathrm{~mol} /\left(\mathrm{m}^{2} \cdot \mathrm{d}\right)$, and the maximum peak point varied with specific species ${ }^{[24]}$. However, everbearing strawberry 'HS138' had 1.4-1.5 times greater dry matter accumulation in the plants at a high DLI $\left(29.2 \mathrm{~mol} /\left(\mathrm{m}^{2} \cdot \mathrm{d}\right)\right)$ than at a low DLI $\left(19.4 \mathrm{~mol} /\left(\mathrm{m}^{2} \cdot \mathrm{d}\right)\right)$, and no adverse effects on plants were found under high DLI and continuous lighting ${ }^{[25,26]}$. The discrepancy in results in response to high DLI may be due to different cultivars and different growth stages in these studies. The light saturation point depends on species, cultivar and growth stage.

3.3 Photon yield and energy yield in runners and runner plants under different daily light integral

Photon yield and energy yield in runners decreased with increasing light intensity regardless of photoperiod (Table 4). There were no significant differences of photon yield in runners under photoperiod between 12 and $16 \mathrm{~h} / \mathrm{d}$ when light intensity was at $200 \mu \mathrm{mol} /\left(\mathrm{m}^{2} \cdot \mathrm{s}\right)$ and $250 \mu \mathrm{mol} /\left(\mathrm{m}^{2} \cdot \mathrm{s}\right)$, respectively. However, photon yield in runners was significantly lower at light intensity of $300 \mu \mathrm{mol} /\left(\mathrm{m}^{2} \cdot \mathrm{s}\right)$ and $350 \mu \mathrm{mol} /\left(\mathrm{m}^{2} \cdot \mathrm{s}\right)$ compared with $200 \mu \mathrm{mol} /\left(\mathrm{m}^{2} \cdot \mathrm{s}\right)$. Photon yield in runner plants followed the same trends as that of runners. The highest photon yield in runners was 0.14 runner $/ \mathrm{mol}$, which was obtained at light intensity of $200 \mu \mathrm{mol} /\left(\mathrm{m}^{2} \cdot \mathrm{s}\right)$ and photoperiod of $16 \mathrm{~h} / \mathrm{d}$, where photon yield in runner plants was also 
highest (0.18 runner plant/mol). The lowest photon yield in runners of 0.07 runner/mol was obtained at light intensity of $350 \mu \mathrm{mol} /\left(\mathrm{m}^{2} \cdot \mathrm{s}\right)$ and photoperiod of $16 \mathrm{~h} / \mathrm{d}$, where photon yield in runner plants was also lowest (0.09 runner plant/mol). Energy yield in runners and runner plants followed the same trends as the photon yield. The higher photon yield value, more runners and runner plants were produced per unit mole photons. $\mathrm{Xu}^{[27]}$ reported that the photon yield in 'Albion' runner plants during the first 12 weeks propagation period and additional 9 weeks propagation period were 0.08 and 0.10 runner plant $/ \mathrm{mol}$, respectively, when cool white fluorescent light in color temperature of $4100 \mathrm{~K}$ was used as the sole light source. In the current experiment, photon yield in runner plants under DLI between 8.6 to $20.2 \mathrm{~mol} /\left(\mathrm{m}^{2} \cdot \mathrm{d}\right)$ was $0.09-0.18$ runner plant $/ \mathrm{mol}$, which was higher compared with that of 'Albion' strawberry.

Table 4 Photon yield and energy yield in runners and runner plants as affected by light intensity and photoperiod

\begin{tabular}{|c|c|c|c|c|}
\hline \multirow{2}{*}{$\begin{array}{c}\text { Treatment } \\
\text { symbol }\end{array}$} & \multicolumn{2}{|c|}{ Photon yield } & \multicolumn{2}{|c|}{ Energy yield } \\
\hline & $\begin{array}{c}\text { Runners } \\
\text { /runner } \cdot \mathrm{mol}^{-1}\end{array}$ & $\begin{array}{l}\text { Runner plants } \\
\text { /runner plant } \cdot \mathrm{mol}^{-1}\end{array}$ & $\begin{array}{c}\text { Runners } \\
\text { /runner } \cdot \mathrm{kWh}^{-1}\end{array}$ & $\begin{array}{l}\text { Runner plants } \\
\text { /runner plant } \cdot \mathrm{kWh}^{-1}\end{array}$ \\
\hline L200-H12 & $0.13 \pm 0.01 \mathrm{a}$ & $0.18 \pm 0.04 \mathrm{a}$ & $0.90 \pm 0.05 \mathrm{a}$ & $1.19 \pm 0.26 \mathrm{a}$ \\
\hline L250-H12 & $0.11 \pm 0.01 \mathrm{~b}$ & $0.15 \pm 0.05 \mathrm{ab}$ & $0.75 \pm 0.08 b$ & $1.00 \pm 0.33 \mathrm{ab}$ \\
\hline L300-H12 & $0.11 \pm 0.01 \mathrm{~b}$ & $0.18 \pm 0.02 \mathrm{a}$ & $0.73 \pm 0.08 \mathrm{~b}$ & $1.16 \pm 0.11 \mathrm{a}$ \\
\hline L350-H12 & $0.10 \pm 0.01 \mathrm{c}$ & $0.15 \pm 0.02 \mathrm{ab}$ & $0.61 \pm 0.06 \mathrm{c}$ & $0.97 \pm 0.15 \mathrm{ab}$ \\
\hline L200-H16 & $0.14 \pm 0.02 \mathrm{a}$ & $0.18 \pm 0.02 \mathrm{a}$ & $0.94 \pm 0.12 \mathrm{a}$ & $1.19 \pm 0.14 \mathrm{a}$ \\
\hline L250-H16 & $0.10 \pm 0.01 \mathrm{bc}$ & $0.13 \pm 0.02 \mathrm{~b}$ & $0.66 \pm 0.07 \mathrm{bc}$ & $0.88 \pm 0.12 b$ \\
\hline L300-H16 & $0.09 \pm 0.01 \mathrm{c}$ & $0.11 \pm 0.02 b c$ & $0.56 \pm 0.09 \mathrm{c}$ & $0.69 \pm 0.15 b c$ \\
\hline L350-H16 & $0.07 \pm 0.01 \mathrm{~d}$ & $0.09 \pm 0.02 \mathrm{c}$ & $0.47 \pm 0.05 \mathrm{~d}$ & $0.60 \pm 0.10 \mathrm{c}$ \\
\hline
\end{tabular}
ANOVA

$\begin{array}{ccccc}\mathrm{L} & * & * & * & * \\ \mathrm{H} & * & * & * & * \\ \mathrm{~L} \times \mathrm{H} & * & * & * & *\end{array}$

Note: The data were expressed as mean \pm standard deviation. $\quad$ Different letters in the same column indicate significant differences according to Duncan's multiple range test at $p \leq 0.05(n=6)$. * significant differences at $p \leq 0.05(n=6)$.

\section{Conclusions}

Light intensity and photoperiod interactively affected the growth of runners and runner plants. Runner elongation can be inhibited by high DLI, which is related to high light intensity and long photoperiod. DLI in a range of $11.5-17.3 \mathrm{~mol} /\left(\mathrm{m}^{2} \cdot \mathrm{d}\right)$ is beneficial to improve propagation efficiency and quality of runner plants, and $11.5 \mathrm{~mol} /\left(\mathrm{m}^{2} \cdot \mathrm{d}\right)$ is optimal for strawberry propagation of runner plants in a plant factory at higher photon and energy yields. Further research is needed to optimize the light quality using different LEDs for more efficient propagation in hydroponic strawberry runner plants propagation.

\section{Acknowledgements}

This work was supported by the National Key Research and Development Program of China (Grant No. 2017YFB0403901). This manuscript was presented at 2019 International Symposium on Environment Control Technology for Value-added Plant Production hold in Beijing at Aug. 27-30, 2019.

\section{[References]}

[1] Paulus A O. Fungal diseases of strawberry. HortScience, 1990; 25: 885-889.

[2] Özdemir E, Kaska N, Gündüz K, Serce S. Strawberry runner tip production on open field for plug plants. Hort Environ Biotechnol, 2009; 50: 3-8.

[3] Stewart P J, Folta K M. A review of photoperiodic flowering research in strawberry (Fragaria spp.). Crit Rev Plant Sci, 2010; 29: 1-13.

[4] Chun C, Kozai T. A closed-type transplant production system. In: Morohoshi N, Komamine A (Ed.), editors. Progress in Biotechnology. Elsevier Academic Press, 2001; 18(01): 375-384

[5] Kubota C, Kozai T. Mathematical models for planning vegetative propagation under controlled environments. HortScience, 2001; 36(1): 15-19.

[6] Chun C. Propagation and production of strawberry transplants. In: Kozai T, Niu GH and Takagaki M (Ed.), editors. Plant factory: An indoor vertical farming system for efficient quality food production. Elsevier Academic Press, 2016; pp. 260-269.

[7] Kozai T, Niu G H. Overview and concept of closed plant production system (CPPS). In: Kozai T, Niu GH and Takagaki M (Ed.), editors. Plant factory: An indoor vertical farming system for efficient quality food production. Elsevier Academic Press, 2016; pp. 3-5.

[8] Smeets L, Kronenberg H G. Runner formation on strawberry plants in autumn and winter. Euphytica, 1955; 4(3): 240-244.

[9] Kim S K, Jeong M S, Park S W, Kim M J, Na H Y, Chun C. Improvement of runner plant production by increasing photosynthetic photon flux during strawberry transplant propagation in a closed transplant production system. Korean J Hortic Sci Technol, 2010; 28: 535-539.

[10] Wu C C, Hsu S T, Chang M Y, Fang W. Effect of light environment on runner plant propagation of strawberry. Acta Hort, 2011; (907): 297-302.

[11] Park S W, Kwack Y, Chun C. Growth of runner plants grown in a plant factory as affected by light intensity and container volume. Hortic Sci Technol, 2017; 35(4): 439-445.

[12] Hamano M, Yamazaki H, Morishita M, Imada S. Effect of chilling and day length on runner of everbearing type strawberry. Acta Hortic, 2009; 842: 671-674.

[13] Hasan S M Z, Isam A M, Aziz A, Yusoff W A B. Effect of photoperiod on propagation of strawberry (Fragaria $\times$ ananassa Duch.). Journal of Horticulture and Forestry, 2011; 3(8): 259-263.

[14] Nishizawa T. Effects of daylength on cell length and cell number in strawberry petioles. J Japan Soc Hort Sci, 1990; 59(3): 533-538.

[15] Nishizawa T. Effects of photoperiods on the length and number of epidermal cells in runners of strawberry plants. J Japan Soc Hort Sci, 1994; 63(2): 347-352.

[16] Goto E. Plant production in a closed plant factory with artificial lighting. Acta Hortic, 2012; 956: 37-49.

[17] Kozai T. Transplant production in closed systems. In: Kozai T, Niu GH and Takagaki M (Ed.), editors. Plant factory: An indoor vertical farming system for efficient quality food production. Elsevier Academic Press, 2016; pp. 237-242.

[18] Arnon D. Copper enzymes in isolated chloroplasts, phytophenoloxidase in Beta vulgaris. Plant Physiol, 1949; 24(1): 1-15.

[19] Chung H Y, Chang M Y, Wu C C, Fang W. Quantitative evaluation of electric light recipes for red leaf lettuce cultivation in plant factories. HortTechnology, 2018; 28(6): 755-763.

[20] Cain M L. Consequences of foraging in clonal plant species. Ecology, 1994; 75: 933-944.

[21] Torres A P, Lopez R G. Photosynthetic daily light integral during propagation of Tecoma stans influences seedling rooting and growth. Hortscience, 2011; 46(2): 282-286.

[22] Pramuk L A, Runkle E S. Photosynthetic daily light integral during the seedling stage influences subsequent growth and flowering of Celosia, Impatiens, Salvia, Tagetes, and Viola. Hortscience, 2005; 40(5): 1336-1339.

[23] Marcelis L F M, Broekhuijsen A G M, Meinen E, Nijs E M F M, Raaphorst M G M. Quantification of the growth response to light quantity of greenhouse grown crops. Acta Hort, 2006; 711: 97-104.

[24] Faust J E, Holcombe V, Rajapakse N C, Layne D R. The effect of daily light integral on bedding plant growth and flowering. HortScience, 2005; 40: 645-649.

[25] Miyazawa Y, Hikosaka S, Goto E, Aoki T. Effects of light conditions and air temperature on the growth of everbearing strawberry during the vegetative stage. Acta Hort, 2009; 842: 817-820.

[26] Yoshida H, Hikosaka S, Goto E. Effects of continuous lighting and time of initiation of treatments on the flowering time and growth of everbearing strawberry nursery plants in a closed plant factory. Journal of Science and High Technology in Agriculture, 2013; 25(2): 77-82.

[27] $\mathrm{Xu} \mathrm{X}$. Optimizing environmental parameters for precision indoor propagation of day-neutral strawberry. Master dissertation. North Carolina: North Carolina State University, 2019; 103p. 